\title{
The Leadership Challenge in Sudan: The Dynamics of Sustainable Failure
}

\author{
Bakry Elmedni, Ph.D \\ Assistant Professor in the Master of Public Administration MPA Program \\ School of Business, Public Administration and Information Sciences \\ LIU Brooklyn, United States \\ Email: bakry.elmedni@liu.edu
}

Received: May 17, 2016 Accepted: June 03, 2016 Published: June 22, 2016

doi:10.5296/jpag.v6i2.9579 URL: http://dx.doi.org/10.5296/jpag.v6i2.9579

\begin{abstract}
This is a theoretical contribution to the historic transformation from traditional type of leadership to modern leadership. In traditional forms of leadership, tribal and sectarian politics are the means through which one can rise to leadership position. In modern leadership forms, knowledge, expertise and education create authority and people can become leaders because of competence and knowledge. The paper is an attempt to partially explain why the latter form of leadership failed and continue to fail in Sudan as well as in other developing nations.
\end{abstract}

Keywords: Leadership, Tribal, Transformation, Authority 


\section{Introduction}

Throughout the history of humanity, societies evolved from traditional types of leadership to modern leadership sometimes through tumult and social upheaval. Because leadership cannot be practiced without power, it might be useful to define what is meant by leadership and explore the sources of power as the foundation of leadership. Bass (1990) noted that there are nearly as many definitions of leadership as there are scholars trying to define it, and that many of these definitions are ambiguous. Another factor that complicates defining leadership is the change in our thinking of leadership as a social phenomenon. When our thinking changes, leadership takes different meaning (Northouse, 2012). In this paper-for the sake of simplicity-leadership is defined as a process of mobilizing others to accomplish a common vision. Thus, in this perspectives, a leader role is to a) develop a vision about the direction that the followers should take, $b$ ) determine a course of action that will accomplish the vision and goals, and c) exercise influence or control in guiding the followers in that direction (Denhardt and Denhadrt \& Aristigueta, 2013). The key element in the role of the leader is influence and/or control. One may wonder, where do leaders get their ability to influence or control followers from? This bring us to the types of power.

Among the early notions about the sources of power is Machiavelli's writing in the $16^{\text {th }}$ century. In his book The Prince, Machiavelli (1947) proposed three provocative ideas. First, he considered people to be "ungrateful, fickle and deceitful" (p. 48). Second, he contended that the state and patriotism comes before everything. Third, he claimed that the sole purpose of political leadership is to gain and maintain power because " a prince should care nothing for the accusation of cruelty so long as he keeps his subjects united and loyal" (p. 47). While Machiavelli's ideas still are used in this age under various justifications, the methods of carrying them out have grown to be more sophisticated. Another early voice is Max Weber. Writing about bureaucracy in early $20^{\text {th }}$ century, Weber argued that there are three types of control mechanisms: 1) charismatic (where power is derived from personal traits and magnetism), 2) traditional (where power comes from family lineage and passed down the new generation), and 3) legal-rational (where laws and constitutional processes create a legitimate authority) (Gerth \& Mills, 1946). Historically, all human societies experienced these three types of power. To this date all these sources of power exist side by side and in some occasions they evolved to complement each other as in the case of constitutional monarchies.

Of particular interest to this paper is the factors that contributed to failure of transition from traditional type of power to modern legal type of power in Sudan. Traditional types of power include, but not limited to, religious sectarianism and tribal leadership. As such, this paper seeks to explore and theorize on some social dynamics that hindered and hampered the progress towards legal-rational types of leadership and governance. The assumption regarding progress is that as societies approach a mature stage of socioeconomic development the role of legal-rational power takes precedence over other forms of control mechanism and leadership. In Sudan, there is a case to be made about a relapse. In the eve of independence in 1956, a relative spread of formal education allowed some individuals to rise to leadership positions through the legal-rational system without having charisma or historical family 
lineage but with the blessing of traditional sources power. Things changed in the decades following the independence as new political leaders emerged without the blessing or support of traditional sources. This was evident in the case of leaders who came through military establishment such as General Aboud in 1959, General Numiri in 1969, and General Al-Bashir in late 1980s. Arguably, formal education and civil service provided a training ground for many people to rise to leadership positions simply because they have what is known as expert power, which will be discussed later in this study. However, it would be naïve to assume that the traditional sources of power were not essential in helping those who rose to leadership positions to become ministers and high-ranking officials in the state's civil service.

Organizationally this paper is divided into five section. In section 2, the discussion focuses on the sources of power and how they might have been undermined, leading to relapse or hindrance of progress toward legal-rational types of leadership. It is ironic that in the second decade of the $21^{\text {st }}$ century, the top leaders in Sudan still legitimize their right to power by using traditional sources either as a direct source for legitimacy or through endorsement. Section 3 focuses on Sudanese civil society and its failure to serve as a medium of transition from traditional type of power to legal-rational type of power. Section 4 provides brief description of research design and methods used to conduct the study. Finally, in section 5, I conclude by proposing new lines of investigation for developing a theory about Sudanese leadership in the $21^{\text {st }}$ century.

\section{Sources of Power in Sudanese Society}

How do people in society acquire power? One of the most powerful research in power is the French and Raven's (1959/1989) book The Bases of Social Power. French and Raven approached power from psychological viewpoint, looking at power as vehicle for influencing or causing psychological change in others. This view focuses on the influence of power on people, such influence is measured by the observed change instigated by a social agent, which could be "a person, a role, a group, or a part of a group" (p. 44). Furthermore, this view assumes change correlates with the amount of power exerted. French and Raven argued that power has the characteristic of potentiality. That means it doesn't have to be used in full capacity under all circumstances. As such, they proposed five sources or bases of power, which will be discussed and applied to broadly to Sudanese society

\subsection{Legitimate Power}

French and Raven (1989) viewed legal power as a source of power that arises from people's beliefs that someone has the right influence on them and that they are obliged to obey. The sources of these beliefs can be religious, political or cultural. These beliefs also can be legitimated, not necessarily through some type of agent such as consultation or election. In organizations - public or private - this power derives from a position or a title. In society, these beliefs usually derive from religious or tribal authority. Probably the best example of such source of power is that reserved to leaders of sophist sects. Some of these leaders wield great deal of power and people willingly comply with their instructions and teachings. The belief that sophist leaders have spiritual superpowers give them unmeasurable psychological 
influence over their followers. None of these leaders are elected by the people who follow them and they usually rise to leadership because of family lineage above all else. There is also some sense of mysticism that surrounds these leaders. Generally speaking, sophist leaders are revered and held to high moral standards; sometimes elevating them beyond the normal human capacity. There are ample examples in which these leaders abuse power and exploit their followers. This is not to mention that many of them are immersed in their earthly activities - their love of wealth and luxury - even though they preach humility, simplicity and hermitism. The problem that these leaders present to progress is that people are unlikely to accept social change without the endorsement of their spiritual idols. The same can be true about tribal leaders since they also possess psychological powers over their followers. Now, the challenge is that social change in terms of embracing modern ways such as rational sources of power usually undermine the authority of these traditional leaders. As a result, progress becomes a sort of self-destruction for sectarian and tribal leaders and it is in their best interests to influence people to view all types of social change as negative phenomena. The writing of the late Mohamoud Mohamed Taha provides vivid examples of this dichotomy between the traditional types of power and the emerging modern types of power. So far, the balance has been and still is titling toward the traditional power. This partially because rational types of leadership have tactically legitimized the traditional sources of leadership so as to gain a foot in a hostile environment. To this date, modern medicine has to compete with traditional healers.

From other societies' experiences there are two models for reconciling this dichotomous relationship between the traditional forms of power and modern rational power. The most common model is the natural change in which the rational model gained more ground because of the expansion of formal education and scientific advances. As a result the social system became a marriage between both types, but the traditional types of leadership redefined itself and became more of a cultural heritage and even relic in some instances. That is to say the traditional types of power no longer try to intervene with the social order created by the legal-rational organization of society. The second model is the social revolution, usually characterized by upheaval, violence and destruction of old ways and building of new ways that cut loose with the old social order.

\subsection{Reward Power}

Reward power derives from our ability to reward people when they do what we want them to do. In a way, rewards serves as a tool to influence behavior by providing positive outcomes and preventing the negative ones. In formal organizations, this is evident in monetary compensations and promotion (French \& Raven, 1989). In society, reward power could have far reaching implications. Those who comply with societal expectations are rewarded with inclusion and a sense of belonging. In tribal life that could mean protection, ability to tend to one's business be it farming or herding and being fully included in the social system that defines life from birth to death. Now, imagine, the price one has to pay for rebelling against the established tribal or spiritual authority. In government, rewards could include hiring, promotion and career success. So, the reward power could be extremely influential in hindering the substitution of traditional types of power with legal-rational ones. Such practice 
was evident in the political behavior of all the authoritarian regimes that ruled Sudan in the past and is evident in the behavior of Al-Bashir's government.

\subsection{Coercive Power}

This is the opposite of reward power and it is usually used to eradicate undesired behavior. Influencing behavior by either coercion or fear of coercion. In organizations, coercive power gives managers and leaders the power to punish by cutting hours, denying promotion or bonus. In society, those who don't abide by the social code of the tribe and religious sect are shunned, excommunicated, crucified or even persecuted. Tribal and religious sectarian leaders wield tremendous amount of coercive power; they adjudicate disputes, punish perpetrators and enforce a legal code that in some instances can be known and understood only by the members. It is no wonder that in Sudan that the vast majority or criminal and civil disputes are never brought to courts and the justice system. In fact, people usually go to court when the social system fails to adjudicate and resolve the disputes. In an environment such as this, social change in terms of transformation from traditional leadership (Omda, sheikh or sultan) to modern leadership (judge, magistrate, court) becomes extremely difficult because of conflict of interests. Some players might not necessarily view the change as positive since it will diminish their influence and exercise of social power.

\subsection{Referent Power}

French and Raven (1959/1989) described referent power as the psychological identification between people. Its influence is dependent on how much someone wants to have a relationship with us or identify with us. That is to say we are influenced by people we like and admire. When we admire people we are likely to see what they do as a favorable, underestimating their flaws and seeking their approval. As a result, we go out of our way to do things that will please the people we like and admire. This gives the people we admire great power in influencing our behavior. In traditional settings, sectarian leaders, and to some extent even tribal leaders, enjoy a degree of influence on their followers that is rarely granted to regular people because of the referent power. The Sudanese social imagination is rich with mythical stories about the sheikhs who healed the sterile and the mentally ill. One wonders, sometimes, if they are religious leaders or just magicians. Would the answer make a difference since the power granted to them by their followers elevate these religious leaders above the flawed humans? Once again, how can we negotiate social change in social conditions in which people think they are better off believing myths and miracles because they cannot imagine other possible worlds. This may sum up the story of social modernization in Sudan. Modernization here better not be conceived in terms of technology and cell phones, but in terms of reconciling modern sources of power with traditional ones in a way that advance and better society.

\subsection{Expert Power}

French and Raven (1959/1989) defined expert power as a power derived from our knowledge and expertise which gives us credibility. Of course, others have to have the opinion that we are knowledgeable otherwise that means we might be delusional. Also our expertise has to be 
valued and needed to give us the ability to influence others' behavior. In organizations, each person is considered an expert in some area. IT personnel are expert in dealing with technological issues, doctors are experts in diagnosing and prescribing medication and so on and so forth. Of all sources of power, expert power stands as a complete opposite to traditional sources of power. This is because expert power derives entirely from tested factual knowledge not myths and miracles. Along the progress spectrum in Sudan, experts once enjoyed a great deal of respect which gave them additional source of influence, referent power. This might be the case today, but what we know for sure in environments where social imagination is rich with all kinds of myths, religious or societal, the expert power tends to diminish. It is not exaggeration that every few months there are news about a traditional healer, usually a sheikh, who can medicate all types of diseases that the modern medicine fail to cure. This could be explained by people's desire to escape their devastating everyday realities, something humans have done to survive throughout history. Nonetheless, such social conditions are ripe for reproduction of the status quo, stalling progress to modern leadership styles. This should not be surprising if the government officially have once declared the use of supernatural powers and metaphysics to build dams, roads and bridges.

\section{Sudanese Civil Society: Is it the Medium of Failure?}

Historically, the transition from traditional to modern types of leadership is mediated through civil society. But let's first define what is meant by civil society as the concept evolved to mean many things in the recent centuries. The notion of civil society is one of the most contentious ideas within political theory. The modern history of civil society can be traced back to John Locke, Adam Ferguson, Hegel and de Tocqueville - that is, roughly back to 1850 (Gibbon, 1998). The 20th century history of the concept, however, started with Gramsci, before disappearing for 50 years, and then reappearing in Eastern Europe in the late 1970s (Gibbon).

Research by Taylor (1991) shows that Locke's view of modern political order depends on associations of free citizens, who are defined in terms of their multiple, distinct and separate economic interests. Hegel viewed civil society as the sphere of pluralism with historically produced corporate and ethical life (Taylor, 1991). The Hegelian version of civil society also includes business and professional associations, and a realm of public debate. Montesquieu (1689-1755) and de Tocqueville (1805-1859) elaborated on the role of professional associations and public debate as mediators between individuals and the state. De Tocqueville (1969) noted that people

Can imagine a society in which all men, regarding the law as their common work, would love it and submit to it without difficulty; the authority of the government would be respected as necessary, not as sacred: the love felt toward the head of state would be not a passion but a calm and rational feeling. Each man having some rights and being sure of the enjoyment of those rights, there would be established between all classes a manly confidence and a sort of reciprocal courtesy, as far removed from pride as from servility. Understanding its own interests, the people would appreciate that in order to enjoy the benefits of society one must shoulder its obligations. Free association of the citizens could then take the place of 
individual authority from the nobles, and the state would be protected both from tyranny and from license. (p.14)

Marx (1843-4) adopted a different view about civil society, describing the separation of the state from civil society as "pantheistic mysticism" (Marx, 1843a, p.62). In criticizing Hegel's thesis that the state possessed a genuinely representative role even in the absence of public election, Marx (1843) contended that in the absence of a democratic system, civil society is nothing but privatized entities, failing to generate forms coherence driven by general social interests. This is because the transition from feudalism to capitalism produced civil society as a realm in which social relations were depoliticized and that apolitical civil societies necessarily tend to produce authoritarian forms of state. Marx's views do not make much sense outside the context of his worldview. That is struggle exists within any form of social interactions, thus civil society and bureaucracy are intertwined because

Bureaucracy must exist to safeguard the imaginary universality of particular interest... the state must be a corporation as long as the corporation wishes to be a state (...) The individual corporation has this same desire for its particular interest against bureaucracy, but desires bureaucracy against the other corporations, against the particular interests. Therefore, bureaucracy, being the completion of the corporation, has the victory over the corporation, which is the incomplete bureaucracy. (Marx, 1843a?: p. 68)

Within that Marxist worldview, however, lies Gramsci, who is credited with revitalizing the debate about civil society. Writing in the aftermath of the failure of the communist revolutions in Central Europe during 1918-21, Gramsci, a communist himself, contended that the concept civil society was part of an effort to understand the qualities and characteristics which enabled Western and Central European states to remain strong in the face of both an economic collapse and an armed insurrection. To Gramsci, civil society is nothing but a bourgeoisie façade that aborted the rise of the masses because

in the case of the most advanced states... civil society has become a very complex structure and one which is resistant to catastrophic incursion of the immediate economic element (crises, depression, etc.). The superstructures of civil society are like the trench systems of modern warfare. In war it would happen that a fierce artillery attack seemed to have destroyed the enemy's entire defensive perimeter; and the moment of their advance and attack the assailants would find themselves confronted by a line of defense which was still intact. (Gramsci, 1971: p. 235)

Gramsci suggested the revolutionary wave was quelled because of a combination of bourgeois state and bourgeois civil society. Gibbon (1998) noted that although Marx did not advocate the destruction of civil society, he agreed with Gramsci that changes to civil society were produced despite the principles of differentiation and exclusivity that govern the dynamics of class struggles and social relations. True to his Marxist ethos, Gibbon (1998) argued that the nature of politics reproduced by civil society is no more than the bourgeois social division of labor. Hence, civil society is a form of the capitalist division of labor in civic guise because "the transition from feudalism to capitalism which created civil society was one which in effect removed the political-collective aspects of feudal social relations 
and substituted legal-individual entities for the old seigniorial ones" (Gibbon, 1998: p. 38).

The general supposition in these discussions, from Locke to Gramsci, is that civil society is conceptualized as having a single indivisible historical role or meaning, which serves philosophically as its essence. Marx and Gramsci might agree that civil society is an entity; however, they clearly believe it is concomitant of capitalist production relations, according to Gibbon (1998). Nonetheless, civil society is assigned distinctive inherent principles, marking clear directions and meaning, that distinguish it from other entities. The relevance of these philosophical views to the discussion of civil society and democracy lies within the concept of pluralism; since pluralism and democracy are equated, it is believed that democracy cannot function without pluralism. Hence, an active civil society is seen as a mechanism for democratization and effective democratic practice. But in Marxist views, the cultivation of civil society is a recipe for de-politicization, producing bureaucracy, constitutional authoritarianism and an absence of democratization.

To this end, Gibbon (1998) contends that the dominant understanding of the notion of civil society is the one that emerged from civil society traditions described by de Tocqueville, which was later incorporated into the mainstream social theory before reappearing in some versions of liberal political thought. Moreover, Gibbon (1998) suggests that the use of civil society, as a concept, is still being dictated by Neo-liberal theorists. Thus, the general theme of contemporary civil society as a realm of autonomy and freedom leads to the reproduction of these values in political practice at the expense of the state and its various apparatuses, similar to the case of East European countries.

Arato (1982) summarizes the characteristics of the dominant contemporary views of civil society in the following ways: founding claims to collective rights on individual ones, not on private property; recognizing and cultivating the significance of particular interests as opposed to general ones; expanding the public space by weakening the existing institutional structures by facilitating new solidarities; and incorporating transparency and participatory forms of self-development.

Similar to the discussion about the essence and meaning of civil society, there is another debate about what constitutes civil society and what it means to be included within the realm of civil society. The mainstream discourse tends to conceive of civil society as member-based organizations, treating these organizations as vibrant, effective vehicles for political mobilization. But some Feminists and other scholars contest the mainstream conceptualization of civil society. Singerman (2006) and Armony (2004) argued that civil society must be expanded to encompass families, social ties and all forms of informal organizations. Armony (2004) goes a step further to argue that civil society cannot always be linked to benign and good virtues. Various debates on civil society as a concept and as an analytic tool will be dealt with in Chapter 2 . 


\section{Methods}

\subsection{Research Design}

This is an exploratory qualitative study built on interviews with leaders in political parties during the past two decades. The paper also built on observation of how people get to be selected to leadership role in political parties, traditional and progressive.

\subsection{Data Processing}

The author conducted in-depth personal interviews with party leaders of Sudanese opposition meetings during conferences and meeting 2000-2008. I asked leaders to explain if they think that their tribal and racial background played a role in elevating them to leadership position. The taped interviews were then transcribed and tabulated around the two themes: 1) individual skills and attributes, and 2) societal factors, focusing mainly on tribe, race and geographic location. During the analysis, the author also build on stories of civil society activists who believed that their tribal affiliations created barriers for success in terms of climbing the ladder to leadership position. These persona narrative then were analyzed through the frame of power as developed by French and Raven (1989). As a word of caution, it is imperative to note that while the tribal and racial tension exist in other countries around the world, each locale has its unique situation. The analytical framework applied in this study might explain the dynamics situations, but the results are unlikely to be typical or the same. The following section provides the findings.

\section{Discussion and Conclusion}

Now, if one is to apply the commonly accepted conceptualization of civil society as a concept, the modern history of Sudanese civil society began with the anti-colonization movement. This generally is linked to the birth of an elitist organization known Mo'tamar Alkherejeen, the Graduate Conference, an organization founded by the early university graduates in 1946. The British authorities founded Gordon Memorial College in 1903, which later became the first university in the country and renamed the University of Khartoum in the 1950s. This college along with other higher secondary schools was established to educate some selective Sudanese youth in order to fill nonessential clerical positions in the government. The general agreement among historians was that it was more cost effective to train selective locals to run the state instead of bringing cadres from the homeland or from Egypt as was the case during the first few decades of the $20^{\text {th }}$ century. It must be noted here that the British Empire was stretched very thin managerially and it was impossible to imagine Brits running civil service from India to the Caribbean and in between.

Around the same time labor trade unions started to appear. Employing the sources of power framework discussed earlier, it should be expected that these educated graduate who are backed by expert power and modern leadership styles would face some push back from the traditional types of power. That was exactly the case. Politically, the educated elite thought about legitimizing their power and increasing their potential control of the state. So what did they do? They divided themselves between the already existing two powerful religious sects: Al-Khatmia and Al-Ansar. Such division was based mainly on tribal and familial ties to the 
two sects. Those who did not join Al Khatmia or Al-Ansar caught the socialist fever of the time and gave birth to Sudanese Communist Party and elaborate trade unions. The model worked for both groups, the religious sects expanded their social legitimacy by claiming rights to the states after independence in 1956, and the elite graduates used traditional sources of power to obtain political leadership positions. The alliance between the educated elite and the two major religious sects gave birth to the two major political parties; Uma National Party and Democratic Unionist Party. Three elected governments and short-lived democratic governance were contested through the same political framework that emerged in the 1950s.

The elite who escaped these two groups became minority political groups. These includes the Sudanese Communist Party and the National Islamic Fronts. The modern types of leadership that rose to political leadership came from military establishment. In a traditional society like Sudan, the military could not and would not be able to govern without either the blessings or aid of the traditional forces of power with its traditional types of leadership. During the three military governments 1959-1964, 1969-1985, 1989-to the present, military ruled by either silent alliance, overt blessing or orchestrated social maneuvering that draws from these traditional sources of power. In the second military rule, President Numiri has attempted to modernize society and to cut loose with the traditional types of leadership, this is at least during 1969-1976. By 1977 Numiri regime went back to the same traditional types of power to legitimate its grip of power, and later in 1978 went further to embrace Islamist groups (Hassan Alturabi and his followers) in search for alternative social legitimacy, which eventually led to its collapse in 1985. Al-Bashir (1989- present) reproduced the traditional types of leadership by using religious fundamentalism to undermine the power of the two major religious sects.

It must be noted here that the civil war in the south, which led to the cession and creation of a new state in 2011, was fought within the same leadership framework by both elected government and military rulers. As the war grew bigger in the 1980s, tribal forces were recruited to fight along with the Sudanese army by utilizing tribal leadership and power. After 1989, Jihad and other forms of Islamic mysticism were also employed to mobilize not-state actors to join the fight. The current wars in Darfour, Blue Nile, and Nuba Mountain (as was in Eastern Sudan) are also approached by the same mentality. The imperative point, however, is that the destruction of the traditional social fabrics brings the assumptions about traditional types of power into question. This is evident in Darfour today, where Uma National Party used to have great social authority and political influence. In a way, the civil war is presenting us with the second model for the transition through revolutions. This process is currently underway, but its final outcome is very hard to predict. That is to say it is unclear whether the same old types of power will continue to have bigger influences on local communities once peace is restored or the old social structure would be completely destroyed.

What is unfortunate is that despite the bloody wars and loss of lives and wealth, Sudanese civil society at the moment does not differ substantially from its form of the 1950s. There are a number of NGOs and CBOs who will not exist without donors' funds but these organizations lack deep roots in the social structure. They are irrelevant in social activities from the perspective of everyday Sudanese people. This is to argue that the balance of 
leadership transition still favors traditional types of power and leadership and if political change is to occur now, regardless of how, the same traditional forces are likely to be in control of the country's political leadership.

Reproduction of leadership failure appears to be the consistent characteristic in the modern history of the Sudan. There are two models that explains transformation from traditional leadership types to modern ones. These models are not mutually exclusive. In fact, they complement each other and the natural forces may furnish the way for revolutionary changes to take place with less violence and social disruption. By the same token, revolutionary changes may accelerate the natural process of transitioning to legal-rational type of leadership. In Sudan, whether the destruction of social fabrics caused by civil wars leads to serious questioning of social assumptions regarding sources of power in society remains to be seen. And whether such questioning will result in lasting changes that open more doors for revolutionary changes or the traditional leadership will reproduce itself in a new social landscape also remains unclear. What is evident, however, is that the traditional types of power are still alive and well, and likely to be a major factor in determining the type of political leadership that will rise to power.

\section{References}

Armony, A. (2004). The Dubious Link: Civic Engagement and Democratization. Stanford: Stanford University Press

Bass, B.M. (1990). Handbook of Leadership. New York, NY: Free Press

Northouse, P.G. (2012). Introduction to Leadership: Concepts and Practice. Thousand Oaks, CA: Sage

Denhardt, R.B, Denhradt, J.V., \&Aristigueta, M.P. (2013). Managing Human Behavior in Public and Nonprofit Organizations (3rd ed.). California, Thousand Oaks, CA: Sage Publications, Inc.

Machiavelli, N. (1947). The Prince (T.G. Bergin, Ed.). New York: Appleton-Century-Crofts.

Gerth, H. H. \& Mills, C. W. (1946). From Max Weber: Essays in Sociology. New York. Oxford University Press

French, J. R., Jr \& Raven, B. (1989). The Bases of Social Power. In J. S. Ott (Ed.), Classic readings in organizational behavior. Belmont, CA: Wadsworth. (Original work published 1959)

de Tocqueville, A. (1969). Democracy in America. (G. Lawrence \& J.P. Mayer, Trans/ Eds). New York: Harper and Row (Original Work Published in 1835)

Gibbon, P. (1998). Some Reflections on 'Civil Society' and Political Change. In L. Rudebeck, O. Tornquist, \& V. Rojas (Eds). Democratization in the Third World: Concrete Cases in Comparative Perspective (23-56). London: McMillan Press LTD 


\section{Macrothink}

Journal of Public Administration and Governance ISSN 2161-7104 2016, Vol. 6, No. 2

Taylor, C. (1991). The Malaise of Modernity. Toronto: Anansi. (Reprinted as the Ethics of Authenticity. Cambridge: Boston: Harvard University Press.)

Marx, K. (1971). Critique of Hegel's Philosophy of Right (D. Mclellan 1971 Ed \& Trans in Early Texts). Oxforord: Blackwell (Original Work Published 1843)

Gramsci, A. (1971). Selection from the Prison Notebook (Hoare. Q. \& G. Nowell-Smith, Eds and Trans.). London: Lawrence \& Wishart.

Singerman, D. (1995). Avenues of participation: Family, politics and Networks in Urban Quarters of Cairo. Princeton University Press.

\section{Copyright Disclaimer}

Copyright for this article is retained by the author(s), with first publication rights granted to the journal.

This is an open-access article distributed under the terms and conditions of the Creative Commons Attribution license (http://creativecommons.org/licenses/by/3.0/). 